\title{
Are Emerging Market Countries Learning to Float?
}

\author{
Dalia S. Hakura
}




\title{
IMF Working Paper
}

Research Department

\section{Are Emerging Market Countries Learning to Float?}

\author{
Prepared by Dalia S. Hakura ${ }^{1}$ \\ Authorized for distribution by Timothy Callen
}

May 2005

\begin{abstract}

\section{This Working Paper should not be reported as representing the views of the IMF.} The views expressed in this Working Paper are those of the author(s) and do not necessarily represent those of the IMF or IMF policy. Working Papers describe research in progress by the author(s) and are published to elicit comments and to further debate.
\end{abstract}

The paper finds that exchange rate flexibility in emerging market countries has increased over the past decade. This "learning to float" appears to have involved a strengthening of monetary and financial policy frameworks aimed at directly addressing the key vulnerabilities that give rise to the "fear of floating." The results in the paper suggest that the trend toward greater exchange rate flexibility, alongside a strengthening of banking supervision, has afforded emerging market countries more monetary policy independence.

JEL Classification Numbers: F33

Keywords: Learning to float; emerging markets; monetary and financial policy frameworks Author(s) E-Mail Address: dhakura@imf.org

\footnotetext{
${ }^{1}$ The author thanks Reza Baqir, Ritu Basu, Tim Callen, Tarhan Feyzioglu, Edward Gardner, James Gordon, Zenon Kontolemis, Tetsuya Konuki, Ashoka Mody, James Morsink, Franziska Ohnsorge, Sam Ouliaris, David Robinson, Jay Shambaugh, Martin Sommer and other colleagues in the IMF for helpful comments and suggestions, and Angela Cabugao, Ioannis Tokatlidis, and Ercument Tulun for research assistance. The author is also grateful to Abdul Abiad and Ashoka Mody for providing data on financial policy frameworks, Marco Arnone for providing data on central bank independence, and Mark Stone and Scott Roger for providing data on dates of adoption of inflation targeting. Remaining errors are my own responsibility.
} 


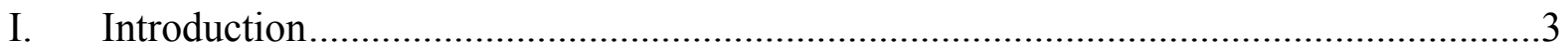

II. The Recent Evolution of Exchange Rate Regimes in EM Countries ...........................4

III. A Descriptive Analysis of Transitions to More Flexible Exchange Rates .....................6

A. From Fixed to Floating: How Have Macroeconomic Outcomes Changed? ................ 7

B. From Fixed to Floating: How Have Macroeconomic Policy Frameworks

Changed?.

IV. Exchange Rate Regimes, Monetary Policy Independence and Policy

Frameworks: An Econometric Analysis ........................................................... 12

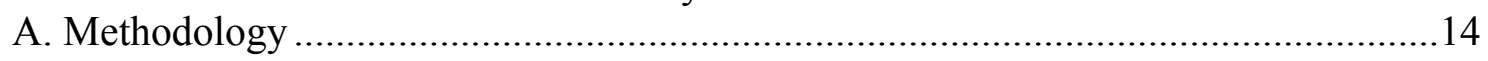

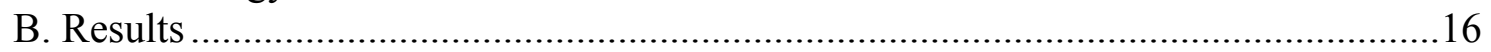

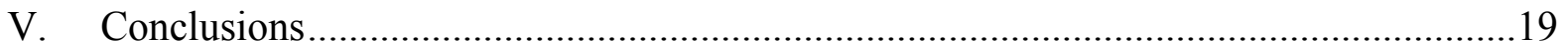

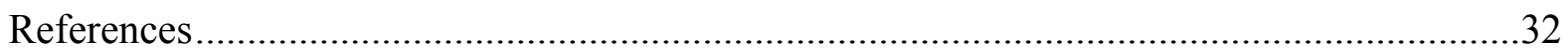

Tables

1. Emerging Market Countries: Transitions to More Flexible Regimes

According to the IMF de facto Classification, 1992-2002 .......................................6

2. Central Bank Independence in Emerging Market Countries .......................................9

3. Exchange Rate Classification and Monetary and Financial Policy Frameworks

in Emerging Market Countries, 2002 ...................................................................13

4. The Responsiveness of Domestic Interest Rates to International Interest Rates ............17

5. Regressions Explaining the Different Responses of Domestic Interest Rates

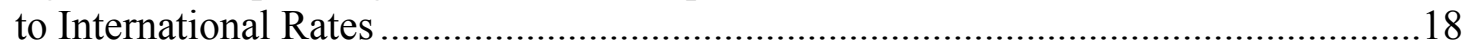

Figures

1. Increasing Exchange Rate Flexibility in Emerging Market Countries .......................21

2. Macroeconomic Indicators..............................................................................22

3. Real Effective Exchange Rate Overvaluation..........................................................23

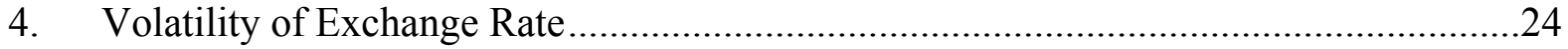

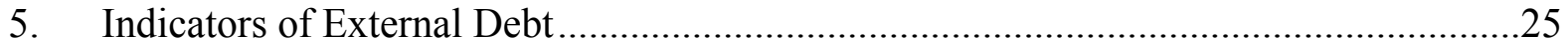

6. Indicators of Financial Sector Supervision and Development..................................26

7. Indicators of Financial Sector Liberalization.........................................................27

Appendix

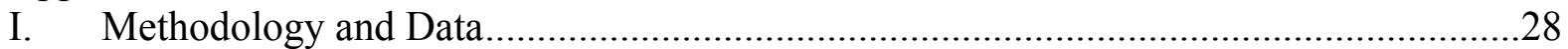




\section{INTRODUCTION}

In many developing countries with limited institutional and policymaking capacity, fixed exchange rate regimes have played a useful role by providing policymakers with a nominal anchor for monetary policy and by helping to establish a degree of policy credibility. By contrast, emerging market (EM) economies - developing countries that are more integrated in global financial markets - have not only had less durable exchange rate regimes than developing countries, they have also more frequently encountered currency crises under pegged exchange rate regimes (Husain, Mody, and Rogoff (2005)). Recent research indicates that the benefits of more flexible exchange rate regimes increase as economies develop economically and institutionally and become more integrated in global financial markets (Rogoff and others (2003 and 2004)). However, notwithstanding the risk of currency crises under pegged regimes and the macroeconomic benefits in terms of growth and inflation performance that flexible regimes have conferred in industrial countries, a "fear of floating" appears to remain in EM countries (Calvo and Reinhart (2002)).

The "fear of floating" appears to derive from the actual or perceived costs of exchange rate volatility. For instance, currency fluctuations may adversely affect competitiveness, cause a ratcheting up of inflation (exchange rate pass-through), and adversely affect balance sheets and debt-servicing burdens by raising the domestic-currency value of foreign-currency-denominated debt. Because of these costs, some policymakers in EM countries believe that the room to pursue an independent monetary policy and increase exchange rate flexibility is, in practice, limited at best (Calvo and Reinhart, 2002, and Hausmann, Panizza, and Stein, 2001).

Recent work has called attention to the importance of strengthening monetary and financial policy frameworks to prepare the ground for the successful introduction of more flexible exchange rate regimes in EM countries. Stronger monetary and financial policy frameworks (or a "learning to float") can reduce the constraints on the conduct of monetary policy. For instance, greater freedom to pursue an independent monetary policy can be provided by a strong central bank that has price stability as its main objective and that has a strong inflation track record. These attributes help stabilize inflation expectations and trim down the pass-through of exchange rate fluctuations to higher prices (Campa and Goldberg, 2001, Choudhri and Hakura, 2001, and Gagnon and Ihrig, 2001). Similarly, strengthened financial sector supervision can help to reduce currency mismatches on banks' balance sheets (Goldstein and Turner, 2004).

This paper makes four contributions to understanding the evolution of exchange rate regimes in EM countries since the early 1990s. First, using the IMF de facto exchange rate classification system, the paper investigates whether there has been a trend toward greater exchange rate flexibility and to what extent these transitions to greater flexibility were driven by crises. The robustness of these findings is checked with the de facto classification system developed by Reinhart and Rogoff (2004). In the process, the paper extends the latter classification system from 2001 to 2003. 
Second, the paper is the first to provide a systematic analysis of the association between evolving monetary and financial policy frameworks and moves toward more flexible exchange rate regimes using newly put together databases on monetary and financial policy frameworks. ${ }^{2}$ It analyzes whether changes in policy frameworks have preceded or followed moves to more flexible exchange rate regimes and whether the association is different for crisis-driven transitions as compared to voluntary transitions. It also compares the current strength of policy frameworks in EMs along with their IMF de facto exchange rate classification. Previous studies of strategies to transit from a peg to a more flexible regime focused only on exploring the association between macroeconomic outcomes and transitions to greater flexibility (see e.g., Eichengreen and others, 1998 and 1999, and Detragiache, Mody, and Okada, 2005).

Third, a distinction is made between transitions from a peg to an intermediate flexible regime, from an intermediate flexible regime to a free float, and from a peg to a free float. This is important to explore the possibility that certain types of transitions may be more strongly associated with a strengthening of monetary and financial policy frameworks than others.

Fourth, the paper provides direct empirical evidence of the link between policy frameworks, monetary policy independence, and exchange rate regimes. Previous work has largely focused on the link between monetary policy independence and the choice of exchange rate regime without controlling for the strength of policy frameworks (see e.g., Frankel, Schmukler, and Servén, 2002, Shambaugh, 2004, and Obstfeld, Shambaugh, and Taylor, 2004).

The paper is organized as follows. Section II examines the evolution of exchange rate regimes in EM economies over the past decade using mainly the IMF's de facto classification system. Section III goes on to examine the association between the 20 transitions to more flexible regimes identified in the study and macroeconomic outcomes and policy frameworks, both before and after the transitions. Section IV examines whether there is a direct empirical link between policy frameworks, monetary independence, and exchange rate regimes. This is done by deriving estimates of monetary policy independence from the sensitivity of domestic interest rates to international interest rates and regressing these estimates on a dummy for countries' with flexible exchange rate regimes and the average values of the strength of policy frameworks in the relevant periods. Conclusions and policy implications are in Section V.

\section{The Recent Evolution of Exchange Rate Regimes in EM Countries}

This section examines the evolution of exchange rate regimes in EM economies over the past decade. ${ }^{3}$ It uses the IMF de facto classification system, and checks robustness with the

\footnotetext{
${ }^{2}$ The association with fiscal policy frameworks is not examined because time series data on fiscal institutions is not available for a large sample of EM countries.

${ }^{3}$ Emerging market economies are defined in the paper as comprising of countries in the Morgan Stanley Capital International index, MSCI (see Appendix 1).
} 
classification system developed by Reinhart and Rogoff (2004). ${ }^{4}$

The IMF de facto classification system suggests that there has been a trend toward greater exchange rate flexibility in EM countries since the early 1990s (Figure 1). In 1991, about twothirds of EM countries were classified as having exchange rate pegs or limited flexibility, and there were no free floats. By 2003, more than two-thirds were classified as managed floats and free floats, of which more than half were free floats. Although the proportions are slightly different, the Reinhart-Rogoff classification picks up the same trends, particularly of a marked increase in the number of countries classified as having a free float. ${ }^{5}$ To keep the analysis manageable, the remainder of the paper distinguishes only three categories of exchange rate regimes: pegs, intermediate regimes (which combine limited flexibility and managed floats), and free floats. At this broader level, exchange rate regimes are classified in the same way by the IMF de facto system and the Reinhart-Rogoff system nearly two-thirds of the time.

The paper defines a transition as a change from one exchange rate category, in which a country has been for at least two years, to another, in which a country remains for at least one year or is followed by another shift in the same direction. According to this definition, the IMF de facto exchange rate classification system identifies 20 transitions to more flexible exchange rate regimes over the past decade and only eight to less flexible regimes. The paper characterizes a transition as either crisis-driven or voluntary. Following Milesi-Ferretti and Razin (2000), a crisis-driven transition is defined as a transition that is associated with an exchange rate depreciation vis-à-vis the U.S. dollar of at least 20 percent, at least a doubling in the rate of depreciation compared to the previous year and a rate of depreciation during the previous year of less than 40 percent. $^{6}$ The transitions that are not crisis-driven are defined as voluntary, although some of these transitions occurred under threat of a crisis. For example, Turkey's adoption of a free float in 2001 does not qualify as crisis-driven, because the rate of exchange rate depreciation in that year was less than double that in the previous year.

The sensitivity of the results to alternative definitions of currency crises is also tested. The first alternative definition of a crisis is the same as the definition above except based on a 25 percent exchange rate depreciation. This definition classifies Thailand and Colombia's transitions as voluntary. The second alternative definition uses the definition of currency crises used by Frankel and Rose (1996), which requires an exchange rate depreciation vis-à-vis the U.S. dollar of 25 percent, which is at least 10 percent higher than the depreciation the previous year. According to this definition, Turkey is characterized as a crisis-driven transition. Since the

\footnotetext{
${ }^{4}$ The paper extends the Reinhart-Rogoff classification system from 2001 to 2003. Appendix I summarizes some key issues in classifying countries' exchange rate arrangements and defines the exchange regime categories used in the paper.

${ }^{5}$ The updated Reinhart-Rogoff classification identifies seven free floats in 2003, compared to ten under the IMF de facto system.

${ }^{6}$ Exchange rate movements that meet these criteria in a three-year window around the exchange regime transition are attributed to the transition.
} 
results in Section III of the paper are fairly robust to how the transitions are classified by the alternative definitions of currency crises, only the results from using the first definition are reported here.

Table 1 shows that the transitions to more flexible regimes are broadly evenly distributed across all geographical regions and across the sample period. No EM country moved directly from a peg to a free float during the sample period. Moreover, crisis-driven and voluntary transitions are both nearly evenly split between transitions from pegs to intermediate floats and transitions from intermediate floats to free floats. The identified transitions are also nearly evenly divided between "voluntary" and "crisis-driven."

Table 1. Emerging Market Countries: Transitions to More Flexible Regimes According to the IMF de facto Classification, 1992-2002 1/

\begin{tabular}{|c|c|c|}
\hline Transition Type & Voluntary & Crisis Driven \\
\hline Peg to Intermediate float & $\begin{array}{l}\text { Czech Republic, } 1996 \\
\text { Egypt, } 1999 \\
\text { Hungary, } 1994 \\
\text { India, } 1995 \\
\text { Pakistan, } 2000\end{array}$ & $\begin{array}{l}\text { Argentina, } 2001 \\
\text { Philippines, } 1997 \\
\text { Thailand, } 1997 \\
\text { Venezuela, } 1996\end{array}$ \\
\hline Intermediate to Free Float & $\begin{array}{l}\text { Chile, } 1999 \\
\text { Peru, } 1999 \\
\text { Philippines, } 2000 \\
\text { Poland, 2000 } \\
\text { South Africa, } 1997 \\
\text { Turkey, 2001 }\end{array}$ & $\begin{array}{l}\text { Brazil, } 1999 \\
\text { Colombia, } 1999 \\
\text { Indonesia, } 1997 \\
\text { Korea, 1997 } \\
\text { Mexico, } 1994\end{array}$ \\
\hline
\end{tabular}

\section{A Descriptive Analysis of Transitions to More Flexible Exchange Rates}

The objective of this section is to examine the association between the 20 transitions to more flexible exchange rate regimes identified above and macroeconomic outcomes and policy frameworks before and after the transitions. In view of the limited number of transitions, the analysis is mainly descriptive. Following standard event-study methodology, the paths of key macroeconomic outcome and policy framework variables in countries making transitions are compared to average values in countries in relevant control groups which did not make a transition. ${ }^{7}$

${ }^{7}$ The control groups consist of countries which did not make transitions and whose exchange rate regime was the same as the starting regime of transiting countries in periods that are not within three years of a transition. Depending on data availability the control group for countries transiting from a peg includes the following countries in the relevant years: Argentina, China, Colombia, Jordan, Malaysia, Morocco, and Thailand. Similarly, the control group for countries transiting from intermediate regimes includes the following countries in the relevant years: Chile, Colombia, Czech Republic, Hungary, India, Indonesia, Israel, Korea, Russia, South Africa, Thailand, and Turkey. 


\section{A. From Fixed to Floating: How Have Macroeconomic Outcomes Changed?}

This section examines the association between transitions to more flexible regimes and macroeconomic outcomes. The key questions are under what macroeconomic conditions have countries made voluntary transitions, and whether voluntary transitions have been associated with an increase in macroeconomic instability. In contrast to earlier work that has analyzed voluntary and crisis-driven transitions together (Eichengreen and others, 1998 and 1999), the focus here is on voluntary transitions.

The behavior of key macroeconomic variables in the years around exchange rate regime transitions is depicted in Figures 2-5. Since the macroeconomic variables fall in broadly similar ranges and there are no clear differences in patterns for the two types of transitions distinguished in the paper (from peg to intermediate float, and from intermediate to free float), the country cases are grouped together in these charts. Given the section's focus on voluntary transitions, the crisis-driven and voluntary transitions are shown separately in the figures. The analysis yields four key results regarding voluntary transitions. ${ }^{8}$

- Voluntary transitions have been made in a macroeconomic environment not significantly different from that in the control group (Figure 2). Pre-transition levels of indicators such as growth, the primary fiscal balance, and the current account balance, were, on average, broadly similar. ${ }^{9}$

- Voluntary transitions were mostly orderly in the sense that growth, inflation, and the primary fiscal balance, among other variables, were on average little affected by the transition. Indeed, voluntary transitions appear to have been associated on average with a sustained decline in inflation, which begins in the years preceding the transition and that continues after the transition. ${ }^{10}$ This finding may reflect in part sample selection bias: the countries that decided to implement a transition may have done so with the expectation that the move would not be disruptive.

- Voluntary transitions were not associated on average with previously over- or undervalued exchange rates. In addition, real effective exchange rates on average were barely affected by these transitions. By contrast, crisis-driven transitions in most cases occurred against the backdrop of an overvalued exchange rate and caused the real effective exchange rate to initially undershoot its estimated equilibrium value (Figure 3 ).

${ }^{8}$ These results are supported by t-tests of equality of averages which are available upon request from the author.

${ }^{9}$ In addition, the ratio of reserves to imports in countries making voluntary transitions were, on average, similar to the control group.

${ }^{10}$ Forecasts of year-ahead inflation from surveys by Consensus Forecasts also suggest that voluntary transitions have on average been associated with a fall in inflation expectations. 
- The volatility of real and nominal effective exchange rates increased somewhat in the period immediately after a voluntary transition but returned to pre-transition levels soon thereafter (Figure 4). ${ }^{11}$ As expected, the increase in exchange rate volatility was both more pronounced and more prolonged in the case of crisis-driven transitions.

Not surprisingly, and consistent with the findings of earlier work, voluntary transitions were associated with lower vulnerabilities and far less macroeconomic disruption than crisis-driven transactions. In the years immediately preceding transitions, the private sector external debt to exports ratio was higher, on average, by 100 percentage points in countries which experienced a crisis-driven transition (Figure 5). This is consistent with the hypothesis that, other things equal, extensive liability dollarization is associated with a greater reluctance on the part of the monetary authorities to float the exchange rate, inducing more liability dollarization and creating a situation from which it is hard to exit in an orderly manner. ${ }^{12}$ In addition, compared to crisis-driven transitions, voluntary transitions have been associated with higher growth, and lower inflation and exchange rate volatility in the immediate post-transition years.

\section{B. From Fixed to Floating: How Have Macroeconomic Policy Frameworks Changed?}

This section investigates the association between transitions to more flexible exchange rate regimes and changes in monetary and financial policy frameworks. The main idea is that strong policy frameworks address the key vulnerabilities that underlie the "fear of floating." The section (i) explains how the strength of the various policy frameworks affect the authorities' credibility and thereby facilitates the conduct of an independent monetary policy that can sustain a flexible exchange rate; and (ii) describes how policy frameworks evolved in the years before and after the transitions to more flexible regimes.

\section{Monetary Policy Framework}

An independent central bank that has price stability as its main objective is more likely to gain the public's confidence that it can and will control inflation. These attributes help stabilize inflation expectations and lower the pass-through of exchange rate fluctuations to higher prices, directly addressing one of the concerns underlying the "fear of floating." The paper examines two measures of monetary policy frameworks:

- $\quad$ Central bank independence is measured using an indicator of political and economic independence, where political independence is inversely related to the extent to which the government is involved in the operations of the central bank, and economic independence is inversely related to the involvement of the central bank in financing the fiscal deficit and in banking supervision (Grilli, Masciandaro, and Tabellini, 1991, and

\footnotetext{
${ }^{11}$ The return to exchange rate stability after the transition to more flexible regimes does not imply a problem with the classification of the post-transition exchange rate regime, as this is based on the volatility of a bilateral exchange rate as well as other factors (see Appendix I).

${ }^{12}$ Data on total foreign currency denominated debt are not available for most countries.
} 
Arnone and Laurens, 2004). Since time-series data on central bank independence are not available, it is not possible to examine how the level of independence changes in the years immediately before and after a transition to greater exchange rate flexibility. Instead, average scores of central bank independence for two years, 1989 and 2003, are compared across countries characterized by their exchange rate regime in 2003 . Table 2 shows that, in the early 1990s, the EM countries for which data are available had similar levels of central bank independence across the range of exchange rate regimes.

However, by 2003, countries with free floats had on average more independent central banks than countries with pegs or intermediate regimes. ${ }^{13}$ It should be noted that, even among countries with free floats, there is considerable variation in the degree of central bank independence.

Table 2. Central Bank Independence in Emerging Market Countries

\begin{tabular}{lccc}
\hline \multirow{2}{*}{ Countries } & $\begin{array}{c}\text { IMF de facto Exchange } \\
\text { Rate Regime in 2003 }\end{array}$ & \multicolumn{2}{c}{$\begin{array}{c}\text { Central Bank Political and Economic } \\
\text { Independence 1/ }\end{array}$} \\
\cline { 3 - 4 } Brazil & Freely floating & 1989 & 2003 \\
Philippines & Freely floating & 0.09 & 0.64 \\
Mexico & Freely floating & 0.46 & 0.82 \\
Peru & Freely floating & 0.36 & 0.82 \\
Poland & Freely floating & 0.55 & 0.73 \\
South Africa & Freely floating & 0.09 & 1.00 \\
Average & & 0.09 & 0.27 \\
& & 0.27 & 0.71 \\
Egypt & Intermediate & 0.55 & 0.46 \\
India & Intermediate & 0.36 & 0.55 \\
Israel & Intermediate & 0.27 & 0.55 \\
Morocco & Peg & 0.18 & 0.64 \\
Average & & 0.34 & 0.55 \\
\hline
\end{tabular}

Sources: Arnone and Laurens (2004); and author's calculations.

$1 /$ Central bank political and economic independence is measured following the definition by Grilli, Masciandaro, and Tabellini (1991). The indicator ranges from 0 to 1, where a higher score indicates a higher level of central bank independence.

- Inflation-targeting. The explicit announcement of an inflation target and the creation of a monetary policy framework geared toward achieving the inflation target can also help to stabilize inflation expectations in countries with flexible exchange rate regimes. It appears that inflation targeting was not a prerequisite for moves to more flexible exchange rate regimes: only one country (Poland) adopted full-fledged inflation targeting before it transited to a free float. Countries that moved to more flexible regimes

${ }^{13}$ The difference between the averages is significant in 2003 when South Africa is excluded from the sample of countries with free floats. 
introduced inflation targeting on average two years after they made the transition. ${ }^{14}$ By 2002, nine of the ten emerging market countries classified as having a free float had adopted inflation targeting, compared with just four out of the ten countries classified with intermediate regimes (Table 3). ${ }^{15}$

\section{Financial Sector Supervision and Development}

Strong financial sector supervision helps banks and other financial market participants to better recognize and price risks, thereby reducing currency and maturity mismatches that can give rise to the "fear of floating." Similarly, securities market development helps to improve long-term funding and thus reduces maturity mismatches. Both the quality of bank supervision and the degree of securities market development are measured using indicators put together by Abiad and Mody (2003). Figure 6 shows the evolution of these indicators in countries making peg-tointermediate and intermediate-to-free float transitions, distinguished by voluntary and crisisdriven transitions, compared to the relevant control groups.

- Quality of bank supervision. ${ }^{16}$ Weak balance sheets, especially currency mismatches, amplify the cost of exchange rate depreciations and thus tend to constrain the conduct of monetary policy as well as the choice of exchange rate regime. Therefore, by strengthening balance sheets, bank supervision can support greater exchange rate flexibility. The countries that made transitions to more flexible regimes had on average better bank supervision before the transition than their respective control groups. Also, crisis-driven transitions were associated with improvements in bank supervision around the time of transition. ${ }^{17}$

- $\quad$ Securities market development. In many EM countries, banks and nonfinancial firms face a shortage of long-term funding. This exposes them to cash flow and liquidity problems, which may constrain the conduct of monetary policy (Mishkin, 1996). The development of longer-term securities markets eases these constraints by lengthening the average maturity of financial instruments in the economy. In fact, countries that moved from intermediate regimes to free floats had above-average securities market

\footnotetext{
${ }^{14}$ Carare and others (2002) provide a review of the initial conditions that can support an inflation-targeting monetary framework.

${ }^{15}$ These findings are robust to the use of the Reinhart-Rogoff exchange rate classification system.

${ }^{16}$ The indicator for the quality of bank supervision captures the adoption of capital adequacy regulations, the power and independence of the supervisory agency, and the extent and effectiveness of supervision.

${ }^{17}$ The improvements in the quality of banking supervision in the countries that had crisis-driven transitions may have been a reaction to the large fiscal costs of cleaning up the banking sector following the crisis, and not a reaction to the adoption of a more flexible regime rate per se.
} 
development compared with the relevant control group. Again, crisis-driven transitions were associated with further securities market development.

\section{Financial Sector Liberalization}

When financial sector supervision is strong and financial institutions are healthy, gradual liberalization generally supports growth (IMF, 2001). However, if financial sector supervision is weak, it may be desirable to maintain financial controls, even while moving ahead with exchange rate flexibility. The extent of liberalization is measured using indicators from Abiad and Mody (2003), with increasing values showing greater liberalization.

- $\quad$ Domestic financial liberalization that is not supported by strong bank supervision can allow excessively risky behavior by the financial sector that weakens balance sheets and thus curtails the central bank's ability to stabilize inflation (Eichengreen and others, 1998). Liberalization may allow insolvent financial institutions to engage in potentially lucrative but risky projects, using expensive funding to "gamble for redemption." Also, by granting banks access to more complex financial instruments, evaluating bank balance sheets may become more difficult. Figure 7 suggests that countries that experienced crisis-driven transitions from pegs to intermediate regimes had, at the time of the transition, on average more liberalized domestic financial systems than countries that made voluntary transitions and than countries in the control group. ${ }^{18}$

- External financial liberalization. As with domestic financial liberalization, if external financial liberalization is not supported by strong financial sector supervision, it can increase risks, such as the potential for sudden reversals of capital inflows. Indeed, countries that made voluntary transitions from pegs to intermediate regimes had, prior to the transition, on average less external financial liberalization than countries that experienced crisis-driven transitions and than countries in the control group. ${ }^{19}$ By contrast, voluntary transitions from intermediate regimes to free floats were associated with a higher degree of external financial liberalization than in the control group, reflecting in part better bank supervision and more advanced securities market development than in the control group.

18 The degree of domestic financial liberalization is measured by a composite index that assesses the extent to which direct credit controls, reserve requirements, and interest rate controls had been abolished, entry barriers against foreign banks had been eliminated, and the banking system had been privatized.

${ }^{19}$ External financial liberalization is measured by a composite rules-based index which captures whether there are restrictions on capital inflows and outflows, and whether the exchange rate system is unified. The main drawback of rules-based measures of capital controls is that they aim to capture restrictions irrespective of their effectiveness. However, using the outcome-based measure of capital controls constructed by Edison and Warnock (2002) yields similar results. 
In addition to the event study of the transitions to greater flexibility, the paper compares the strength of monetary and financial policy frameworks in the 25 EM countries in the study along with their IMF de facto exchange rate classification and the updated Reinhart-Rogoff classification in 2002. The data, summarized in Table 3, indicates a positive relation between exchange rate flexibility and the strength of monetary and financial policy frameworks. Countries with free floats on average have stronger financial sector supervision than countries with pegs or intermediate regimes. However, even among countries with free floats there is substantial variation in the quality of bank supervision. Moreover, financial sector supervision in countries with intermediate regimes is not significantly stronger than those in countries with pegs. This could partly reflect the experience with financial crises in the 1990s; countries that maintained pegs appear to have substantially strengthened the quality of their banking supervision. The data also indicates a positive relation between exchange rate flexibility and securities market development. This association is robust to using the updated Reinhart-Rogoff classification. Countries with freely floating exchange rates on average have a higher degree of domestic and external financial liberalization than countries with pegs or intermediate regimes. However, the differences in the averages across exchange rate regimes are not statistically significant.

\section{Exchange Rate Regimes, Monetary Policy Independence and Policy FrAMEWORKS: AN ECONOMETRIC ANALYSIS}

The analysis up to now suggests that stronger monetary and financial policy frameworks can help countries "learn to float" and facilitate the introduction of more flexible exchange rate regimes. However, it does not provide direct empirical evidence of the link between policy frameworks, monetary policy independence, and the choice of exchange rate regime. This section applies commonly used methodologies to proxy monetary policy independence by the sensitivity of domestic interest rates to foreign interest rates (see e.g. Frankel, Schmukler, and Servén (2002), Shambaugh (2004) and Obstfeld et al. (2004)). It then empirically examines the relationship between the estimates of monetary policy independence and policy framework variables. The empirical evidence implies that stronger policy frameworks provide countries with greater monetary policy independence and thereby can facilitate the introduction of flexible exchange rate regimes.

The remainder of this section is divided into two parts. The first part describes the methodology used to estimate the sensitivity of domestic interest rates to foreign interest rates for each country with a given exchange rate regime. The second part applies the methodology to the EM countries over the 1992-2003 period distinguished by their exchange rate regime. It then regresses the estimates of monetary policy independence on the policy framework variables suggested in the previous section and a dummy for countries' with flexible exchange rate regimes. 
Table 3. Exchange Rate Classification and Monetary and Financial Policy Frameworks in Emerging Market Countries, 2002

\begin{tabular}{|c|c|c|c|c|c|c|}
\hline \multirow[t]{3}{*}{$\begin{array}{l}\text { IMF de facto } \\
\text { Classification }\end{array}$} & \multirow[t]{3}{*}{$\begin{array}{c}\text { Updated } \\
\text { Reinhart-Rogoff } \\
\text { Classification }\end{array}$} & \multirow{3}{*}{$\begin{array}{l}\text { Monetary Framework } \\
\text { Inflation Targeting 1/ }\end{array}$} & \multicolumn{4}{|c|}{ Financial Policy Frameworks 2/ } \\
\hline & & & \multirow{2}{*}{$\begin{array}{l}\text { Bank } \\
\text { Supervision }\end{array}$} & \multirow{2}{*}{$\begin{array}{l}\text { Securities } \\
\text { Markets }\end{array}$} & \multicolumn{2}{|c|}{ Financial Liberalization } \\
\hline & & & & & Domestic & External \\
\hline \multicolumn{7}{|l|}{ Peg } \\
\hline China 3/ & Peg & No & 1 & 1 & 1 & 1 \\
\hline Jordan 3/ & Peg & No & 2 & 1 & 3 & 3 \\
\hline Malaysia & Peg & No & 2 & 2 & 2 & 3 \\
\hline Morocco & Intermediate & No & 1 & 2 & 2 & 1 \\
\hline $\begin{array}{l}\text { Venezuela } \\
\text { Intermediate }\end{array}$ & Peg & No & 1 & 3 & 2.5 & 3 \\
\hline Hungary $3 /$ & Intermediate & Yes & 3 & 3 & 3 & 3 \\
\hline Israel & Intermediate & Yes & 1 & 3 & 2.5 & 3 \\
\hline Argentina & Intermediate & No & 1 & 2 & 2 & 1 \\
\hline Czech Republic 3/ & Freely Floating & Yes & 2 & 3 & 2.75 & 3 \\
\hline Egypt & Intermediate & No & 1 & 2 & 2 & 2 \\
\hline India & Intermediate & No & 2 & 2 & 1 & 3 \\
\hline Indonesia & Freely Floating & No & 1 & 3 & 2 & 2 \\
\hline Pakistan & Intermediate & No & 1 & 2 & 1.75 & 1 \\
\hline Russia 3/ & Intermediate & No & 2 & 1 & 2.5 & 1 \\
\hline $\begin{array}{l}\text { Thailand } \\
\text { Freely Floating }\end{array}$ & Intermediate & Yes & 2 & 2 & 2.5 & 2 \\
\hline Brazil & Freely Floating & Yes & 1 & 3 & 1.5 & 2 \\
\hline Chile & Freely Floating & Yes & 3 & 3 & 2.75 & 3 \\
\hline Colombia & Intermediate & Yes & 2 & 3 & 2.25 & 3 \\
\hline Korea & Freely Floating & Yes & 2 & 3 & 2 & 3 \\
\hline Mexico & Intermediate & Yes & 2 & 3 & 2.75 & 3 \\
\hline Peru & Intermediate & Yes & 2 & 2 & 3 & 3 \\
\hline Philippines & Intermediate & Yes & 1 & 2 & 2.75 & 2 \\
\hline Poland 3/ & Intermediate & Yes & 3 & 2 & 2.75 & 3 \\
\hline South Africa & Freely Floating & Yes & 3 & 3 & 3 & 3 \\
\hline Turkey & Freely Floating & No & 3 & 3 & 2 & 3 \\
\hline $\begin{array}{l}\text { IMF de Facto } \\
\text { Classification }\end{array}$ & & Average by Type of Exchan & & & & \\
\hline Peg & & & $\begin{array}{l}1.40 \\
(0.55)\end{array}$ & $\begin{array}{l}1.80 \\
(0.84\end{array}$ & $\begin{array}{l}2.10 \\
(0.74)\end{array}$ & $\begin{array}{c}2.20 \\
(1.10)\end{array}$ \\
\hline & & & 1.60 & 2.30 & 2.20 & 2.10 \\
\hline Intermediate & & & $(0.70)$ & $(0.67)$ & $(0.57)$ & $(0.88)$ \\
\hline Freely floating & & & $\begin{array}{l}2.20 \\
(0.79)\end{array}$ & $\begin{array}{c}2.70 \\
(0.48)\end{array}$ & $\begin{array}{l}2.48 \\
(0.51)\end{array}$ & $\begin{array}{r}2.80 \\
(0.42)\end{array}$ \\
\hline $\begin{array}{l}\text { test for equality p-value } 4 \text { / } \\
\text { Reinhart-Rogoff }\end{array}$ & & & 0.086 & 0.035 & 0.426 & 0.131 \\
\hline & & & 1.50 & 1.75 & 2.13 & 2.50 \\
\hline Peg & & & $(0.58)$ & $(0.96)$ & $(0.85)$ & $(1.00)$ \\
\hline & & & 1.60 & 2.07 & 2.18 & 2.07 \\
\hline Intermediate & & & $(0.83)$ & $(0.80)$ & $(0.80)$ & $(1.03)$ \\
\hline Freely floating & & & $\begin{array}{c}2.14 \\
(0.90)\end{array}$ & $\begin{array}{l}3.00 \\
(0.00)\end{array}$ & $\begin{array}{l}2.29 \\
(0.55)\end{array}$ & $\begin{array}{c}2.71 \\
(0.49)\end{array}$ \\
\hline Test for equality $p$-value $4 /$ & & & 0.347 & 0.005 & 0.822 & 0.420 \\
\hline
\end{tabular}

$1 /$ The source is Stone and Roger (2004).

2/The indicators for financial policy frameworks take values from 0 to 3, with increasing values indicating stronger bank supervision, greater securities market development, and more domestic and external financial liberalization, respectively. The source of the data is Abiad and Mody (2003).

$3 /$ The data on the strength of financial policy frameworks for these countries is based on responses by IMF desk economists to a questionnaire in 2004. It should be noted that bank supervision in China improved significantly during 2004, as the authorities passed a number of regulations in line with international best practice. The figures for China in this table reflect past, rather than current conditions.

4/The p-value tests the null hypothesis that the average values for the exchange rate regimes are equal to each other. A p-value of 0.05 indicates that the average values for the exchange rate regimes are statistically significantly different from each other at the 5 percent level. 


\section{A. Methodology}

The paper estimates the responsiveness of domestic interest rates to international interest rates separately for each country-exchange rate regime period. Following Frankel, Schmukler, and Servén (2002), the long-run interest rate relation is specified as follows:

$$
R_{t}=a+\beta_{1} R_{t}^{*}+\beta_{2} X_{t}+u_{t}
$$

where $R_{t}$ is the domestic nominal interest rate in local currency at time $\mathrm{t},{ }^{20} R_{t}^{*}$ is the international interest rate (proxied by the 90-day US T-bill rate), and $X_{t}$ is a set of control variables that includes (i) a dummy variable to control for currency crises; ${ }^{21}$ and (ii) the difference between the domestic and foreign inflation rates to proxy variations in the domestic nominal interest rates that reflect variations in a country's risk premium over time. ${ }^{22} 23$

The parameter $\beta_{1}$ measures the degree of monetary independence and is expected to be positive. The theoretical prediction is that, for a given degree of capital mobility and other factors, more flexible exchange rates allow countries to pursue a more independent monetary policy implying a lower sensitivity of domestic interest rates to foreign interest rates; in other words, it is expected that $\beta_{1 \text { peg }}>\beta_{\text {lintermediate }}>\beta_{1 \text { freefloat }}$. In the extreme case of a pegged exchange rate regime and full capital mobility, it is expected that $\beta_{1}=1$. At the other extreme, with a free float and full capital mobility, $\beta_{1}$ is expected to be close to zero, except if shocks are highly correlated across relevant countries.

The parameter estimates of monetary independence for each country-exchange rate regime period obtained from regressions of equation (1) are then regressed on the average values of the policy framework variables proposed in the previous section over the relevant periods and an exchange rate regime dummy. Given the limited number of observations (country-exchange

${ }^{20}$ In line with Frankel, Schmukler, and Servén (2002) and Shambaugh (2004), the interest rate, $R$, is defined as $\ln (1+R)$.

${ }^{21}$ The currency crises dummy is defined to equal one if the percentage change in the exchange rate over a three-month period is equal to or greater than 20 percent.

22 The parameter estimates are robust to estimating the regressions instrumenting for possible endogeneity of the inflation differential using one or two lags of the inflation differential as instruments. They are also robust to proxying the risk premia by adjusting the international interest rate for the anticipated exchange rate depreciation proxied by the actual depreciation rate over the year.

${ }^{23}$ Episodes of hyperinflation, defined as monthly inflation over 40 percent, are excluded from the regressions. 
regime periods), the analysis in this section does not distinguish between the intermediate and free float flexible exchange rate regimes. Thus, the dummy for flexible regimes is for the countries classified with intermediate flexible, and freely floating regimes. Since the estimates of monetary independence cover various periods, the regression could only include the variables for which time series data was available. ${ }^{24}$ The basic regression took the following form:

$$
\begin{aligned}
& \beta_{1}=\alpha+\tau_{1} \text { Flexible Regime Dummy }+\tau_{2} \text { External Financial Liberalization }+ \\
& \tau_{3} \text { Domestic Financial Liberalization }+\tau_{4} \text { Bank Supervision } \\
& +\tau_{5} \text { Securities Market Development }+\tau_{6} \text { Percent Time Inflation Targeting }+\varepsilon
\end{aligned}
$$

Controlling for other factors, the flexible regime dummy is expected to be associated with a lower responsiveness of domestic interest rates to foreign interest rates. ${ }^{25}$ The estimated coefficients for $\tau_{2}$ and $\tau_{3}$ are expected to be positive, as external and domestic financial liberalization which proxy for the removal of capital controls or interest rate controls, are expected to increase the sensitivity of domestic interest rates to foreign interest rates. ${ }^{26}$ The converse of this argument is that if interest rates are set administratively or if there are barriers to international capital mobility, domestic interest rates can move independently from international interest rates, thereby maintaining monetary independence in countries with pegged exchange rate regimes. As discussed in the previous section, the strengthening of financial and monetary policy frameworks allows for the pursuit of more independent monetary policy. Therefore, the coefficient estimates for $\tau_{4}, \tau_{5}$ and $\tau_{6}$ are expected to be negative, reflecting a lower responsiveness of domestic interest rates to foreign interest rates with stronger regulatory, supervisory, and monetary policy frameworks. ${ }^{27}$

\footnotetext{
${ }^{24}$ The inflation targeting dummy is averaged over the period for which the $\beta_{1}$ coefficient is estimated. It thus represents the percentage of time the country implemented inflation targeting.

${ }^{25}$ Shambaugh (2004) undertakes a similar exercise but focuses on the role of trade integration, financial exposure, and the level of industrialization on the correlation of local and domestic interest rates rather than on the strength of countries macroeconomic policy frameworks.

${ }^{26}$ The domestic liberalization variable captures whether or not there are interest rate and credit controls, the degree of state ownership of the banking sector and restrictions on the entry of foreign banks. It thus directly captures whether interest rates are set in a market.

${ }^{27}$ Monetary policy frameworks can be strengthened in more than one way. However, the paper only tests for the strengthening of monetary policy implementation through the adoption of an inflation targeting framework.
} 


\section{B. Results}

Equation (1) is estimated for each country-exchange regime period longer than two years using monthly data obtained from the IMF's International Financial Statistics (IFS) ${ }^{28}$ By requiring a minimum of two years of data to estimate equation (1) a number of observations are lost. Moreover, the analysis in the section is limited to the countries for which time-series data on monetary and financial policy frameworks are available. ${ }^{29}$

Table 4 presents the results from estimating equation (1) for each EM country in the sample with the relevant exchange rate regimes. ${ }^{30}$ For each country-exchange regime period the slope parameter $\beta_{1}$ that measures the degree of monetary independence is reported, as well as the $\mathrm{p}$ value for the test of the null hypothesis that $\beta_{1}=1$. The breakdown between countries with limited flexible and managed floating regimes in the intermediate flexible regime category is shown in this table. The results are similar to those obtained by Frankel, Schmukler and Servén (2002). The estimates of monetary independence are generally not significantly different from one across the exchange rate regimes. Moreover, the parameter estimates are not systematically smaller for countries with free floats than for the other countries.

By construction, the precision with which the $\beta_{1}$ coefficients in equation (1) are estimated varies, owing to heteroskedastic errors. To deal with this, equation (2) is estimated by weighted least squares (WLS), using the inverse of the standard error of the $\beta_{1}$ estimates as weights thereby giving less weight to less precise estimates of monetary independence. Accordingly, the results are reported in Table 5. The results reported in Column 1 suggest that countries with flexible regimes are afforded greater monetary autonomy relative to countries with fixed exchange rate regimes: domestic interest rates in countries with flexible exchange rate regimes are less responsive to changes in international rates than countries with pegged regimes. Also, as expected, the external and domestic financial liberalization variables have a positive effect on the responsiveness of domestic interest rates, though only the effect of the domestic financial liberalization variable is significant. The results in Column 2 which include the policy framework variables in the regression show that while the estimates of the responsiveness of domestic interest rates to international rates are not significantly affected by the degree of

${ }^{28}$ Following Shambaugh (2004), depending on the data availability, domestic interest rates are measured using either the money market or treasury bill data from the IMF's IFS, whichever series is available for a longer time span.

${ }^{29}$ Countries with implausible estimates of $\beta_{1}$ are also excluded. This includes two countries which had negative estimates of $\beta_{1}$ that were based on two years of data, and India over the January 1995-May 1998 period which had a value of $\beta_{1}=7.1$.

${ }^{30}$ Although some studies (e.g. Shambaugh, 2004) have shown that interest rate series in finite samples appear borderline nonstationary, augmented Dickey-Fuller unit root tests that allow for changes in the exchange rate regimes suggest stationarity of the interest rate series. 


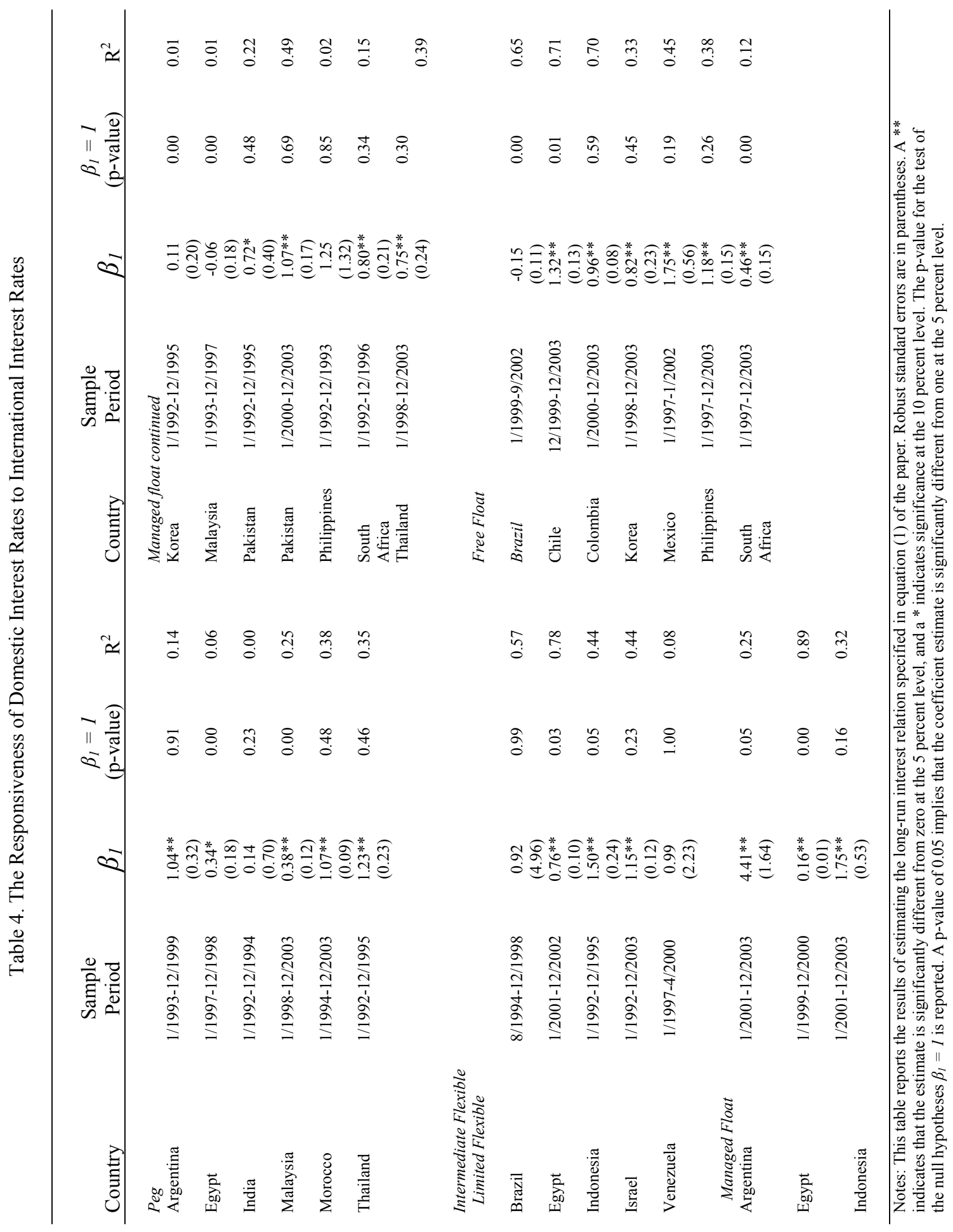


Table 5. Regressions Explaining the Different Responses of Domestic Interest Rates to International Rates

\begin{tabular}{lcc}
\hline Equation & 1 & 2 \\
\hline Constant & -0.93 & -0.72 \\
& $(0.65)$ & $(1.40)$ \\
Flexible Exchange Regime Dummy & $-0.65^{* *}$ & $-0.74^{* *}$ \\
& $(0.29)$ & $(0.14)$ \\
External Financial Liberalization & 0.23 & -0.25 \\
Domestic Financial Liberalization & $(0.29)$ & $(0.33)$ \\
& $0.66^{* *}$ & $1.05^{* *}$ \\
Quality of Bank Supervision & $(0.30)$ & $(0.41)$ \\
Securities Market Development & & $-0.34^{* *}$ \\
Inflation Targeting & & $0.12)$ \\
Number of Observations & & 0.18 \\
Adjusted R-squared & & $0.51)$ \\
& & $(0.68)$ \\
\end{tabular}

Notes: The dependent variable in the regressions is the estimated response of domestic interest rates to international rates. The regressions are estimated using weighted least squares (see text for further explanation). Robust standard errors are reported in parentheses. A** denotes significance at the 5 percent level. 
securities market development and the share of the sample period countries have implemented inflation targeting, the estimates are negatively and significantly related to the quality of banking supervision. This suggests that better-quality banking supervision increases the degree of monetary autonomy. ${ }^{31}$ In addition, the adjusted $R^{2}$ increases significantly in the WLS regression that includes the policy framework variables suggesting that they explain a large share of the variation of the responsiveness of domestic to international interest rates. ${ }^{32} 33^{\circ}$

\section{Conclusions}

The paper finds evidence that exchange rate flexibility in emerging market countries has increased substantially over the past decade. The share of EM countries with free floats rose from virtually zero in the early 1990s to more than one-third in recent years. While there have been some transitions toward less flexible regimes, most have been toward greater flexibility. The numbers of peg-to-intermediate and intermediate-to-free float transitions were broadly similar, and both were nearly evenly split between voluntary and crisis-driven transitions. There were no transitions from pegs to free floats in the sample. Moreover, the transitions were broadly evenly distributed across regions.

The paper explores the conditions under which EM countries voluntarily moved to more flexible exchange rate regimes. One key finding is that voluntary transitions were generally not associated with an increase in macroeconomic instability. Although the results are based on a small sample and could reflect sample selection bias, key indicators such as growth and real exchange rate overvaluation, among others, were on average little affected by the transition. Indeed, inflation performance continued to improve after the transitions, and, while exchange rate volatility increased somewhat immediately after the transitions, it soon returned to a level similar to that in the pre-transition period.

Another key finding of the paper is that the transitions to greater exchange rate flexibility were generally associated with a strengthening of monetary and financial policy frameworks,

${ }^{31}$ The empirical analysis assumes that improvements in policy frameworks precede countries beginning to exercise monetary policy independence. It is conceivable, however, that countries start exercising monetary policy independence upfront and subsequently move towards strengthening their policy frameworks. Given data limitations, it was not feasible to apply an instrumental variables analysis to address possible simultaneity issues.

${ }^{32}$ Moreover, the WLS regression estimation results are robust to omitting the extreme estimates of monetary policy independence as measured by the observations with the two highest and lowest absolute values of the t-statistics (not reported here).

${ }^{33}$ The discussion in the previous section of the importance of bank supervision in liberalized financial markets indicates that there may also be interaction effects between the two financial liberalization variables and bank supervision. However, the estimated coefficients for the relevant interaction terms were not statistically significant at conventional levels of significance. 
consistent with the idea that such moves can be facilitated by investing in "learning to float." Countries making voluntary transitions had strengthened bank supervision compared with the countries in the control group. Countries that made voluntary transitions from intermediate to free floats also developed their securities markets further. In addition, the countries with crisisdriven transitions improved bank supervision and, in the case of intermediate to free float transitions, further developed securities markets around the time of transition. Moreover, compared with the average behavior in the relevant control group, transitions to greater exchange rate flexibility over the past decade have been associated with increased central bank independence and the adoption of inflation targeting.

The analysis suggests that not all policy frameworks have to be in place for countries to make a transition to a more flexible regime. The evidence suggests, for example, that even in countries that already have free floats there remains scope to further strengthen policy frameworks. Also, most EM countries that moved to a free float introduced full-fledged inflation targeting only after the transition. Furthermore, countries making a voluntary first step toward exchange rate flexibility had on average less financial liberalization than the control group.

The empirical analysis suggests that — at an aggregated level — the adoption of more flexible exchange rate regimes in EM countries has been associated with greater monetary policy independence; the responsiveness of domestic interest rates to international rates is smaller for EM countries with flexible exchange rate regimes than for those with pegged exchange rate regimes controlling for the degree of financial liberalization. Among the policy framework variables, bank supervision appears to be the main variable driving the responsiveness of domestic interest rates to foreign interest rates thereby also suggesting that better-quality banking supervision can help facilitate the introduction of flexible regimes.

The findings from the empirical analysis are in line with those from the descriptive analysis. In particular, they support the finding that the emerging markets' moves to greater flexibility have been associated with increased monetary policy independence controlling for the degree of financial liberalization. They also suggest that emerging market economies" "learning to float" has involved increasing their monetary autonomy through a strengthening of monetary and financial policy frameworks, particularly by improving banking supervision. 
Figure 1. Increasing Exchange Rate Flexibility in Emerging Market Countries (Percent of annual observation)

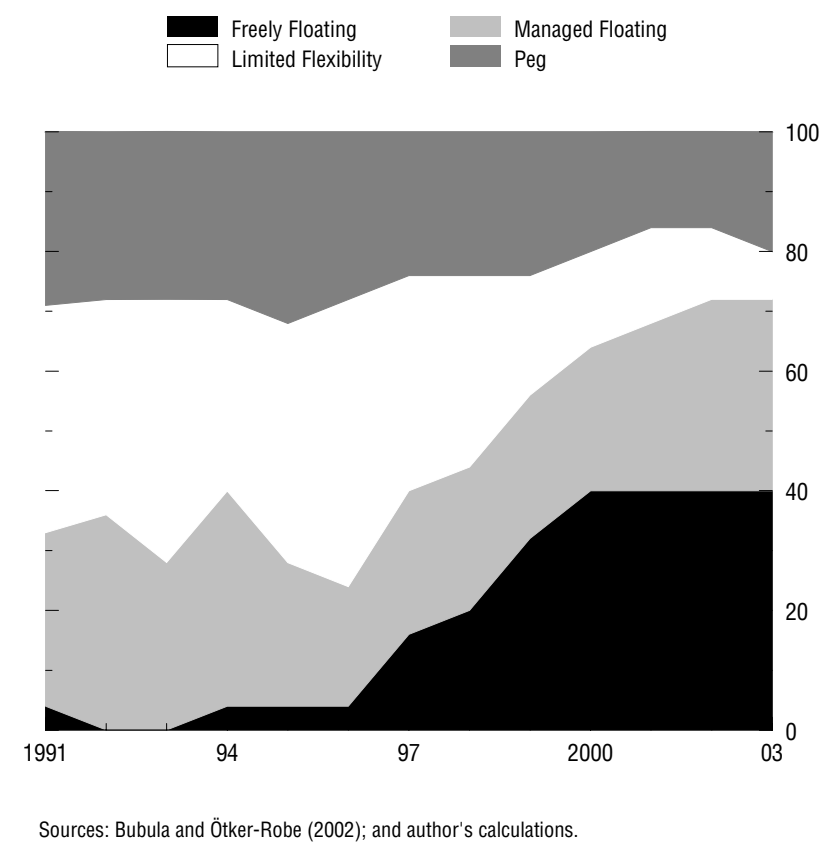


Figure 2. Macroeconomic Indicators ${ }^{1}$

(Percent unless otherwise noted; $\mathrm{t}=0$ is year of transition)

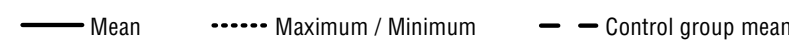

Voluntary

Crisis-Driven
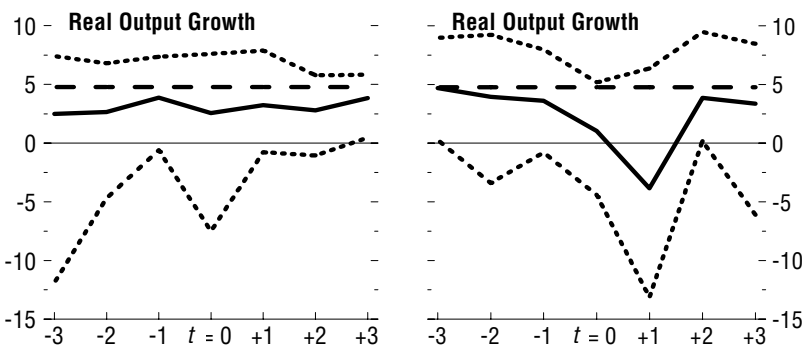

50 - Inflation

40

30

20
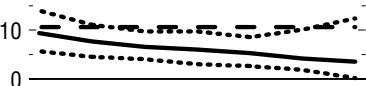

$\begin{array}{lllllll}-10 & 1 & 1 & 1 & 1 & 1 & 1 \\ -3 & -2 & -1 & t=0 & +1 & +2 & +3\end{array}$

- Inflation

$-50$
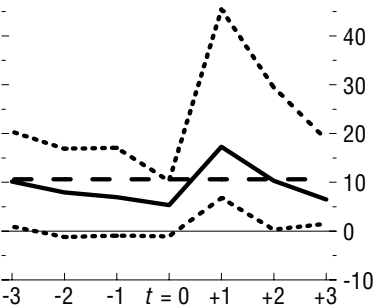

15 - Primary Fiscal Balance (percent of GDP)

10
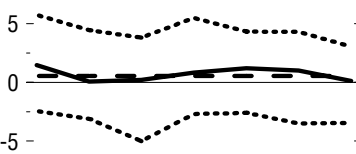

- Primary Fiscal Balance $\quad-15$ (percent of GDP)
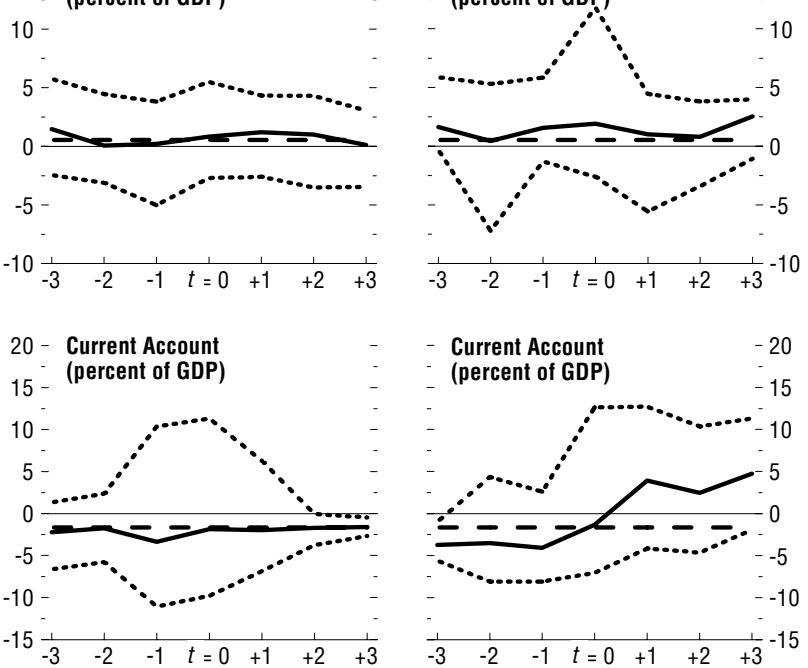

Sources: World Bank, World Development Indicators; IMF, International Financial Sources: World Bank, World Developr
Statistics; and author's calculations.

${ }^{1}$ The control group represents countries whose exchange rate regimes are the same as the starting regimes of transitioning countries in periods that are not within three years of a transition. Outliers are excluded from the panel for inflation. 
Figure 3. Real Effective Exchange Rate Overvaluation ${ }^{1}$ (Percent deviation from trend; $\mathrm{t}=0$ is month of transition)

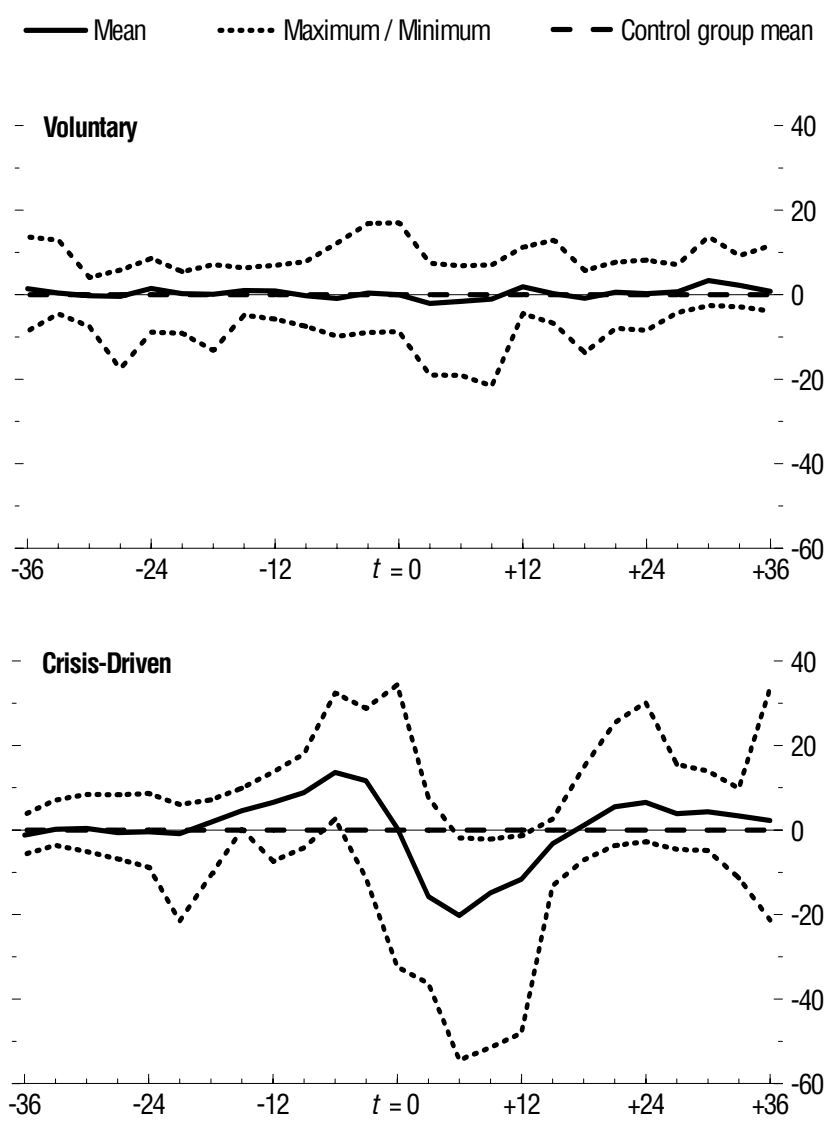

${ }^{1}$ Real exchange rate overvaluation is calculated using the percentage difference between the actual real effective exchange rate (REER) and the Hodrick-Prescott filter of the REER. The control group represents countries whose exchange rate regimes are the same as the starting regimes of transitioning countries in periods that are not within three years of a transition. 
Figure 4. Volatility of Exchange Rate ${ }^{1}$ $(\mathrm{t}=0$ is month of transition)

- Mean $\quad$...... Maximum / Minimum $\quad-\quad-$ Control group mean

Voluntary
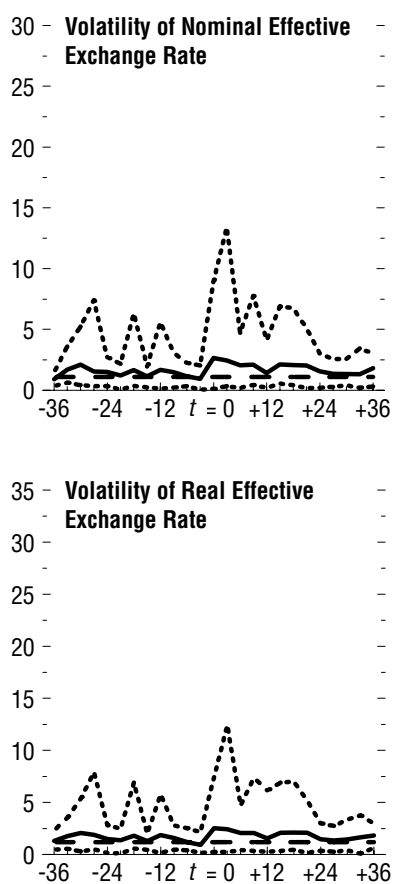

Crisis-Driven

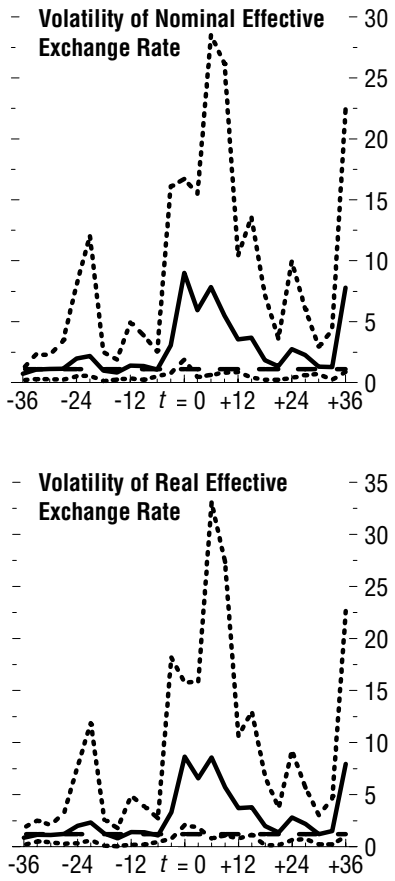

${ }^{1}$ Volatility is measured as the standard deviation of the monthly growth rate of the exchange rate over the last three months, averaged across transition cases. The control group represents countries whose exchange rate regimes are the same as the starting regimes of transitioning countries in periods that are not within three years of a transition. 
Figure 5. Indicators of External Debt ${ }^{1}$

(Percent of exports of goods and services; $t=0$ is year of transition)

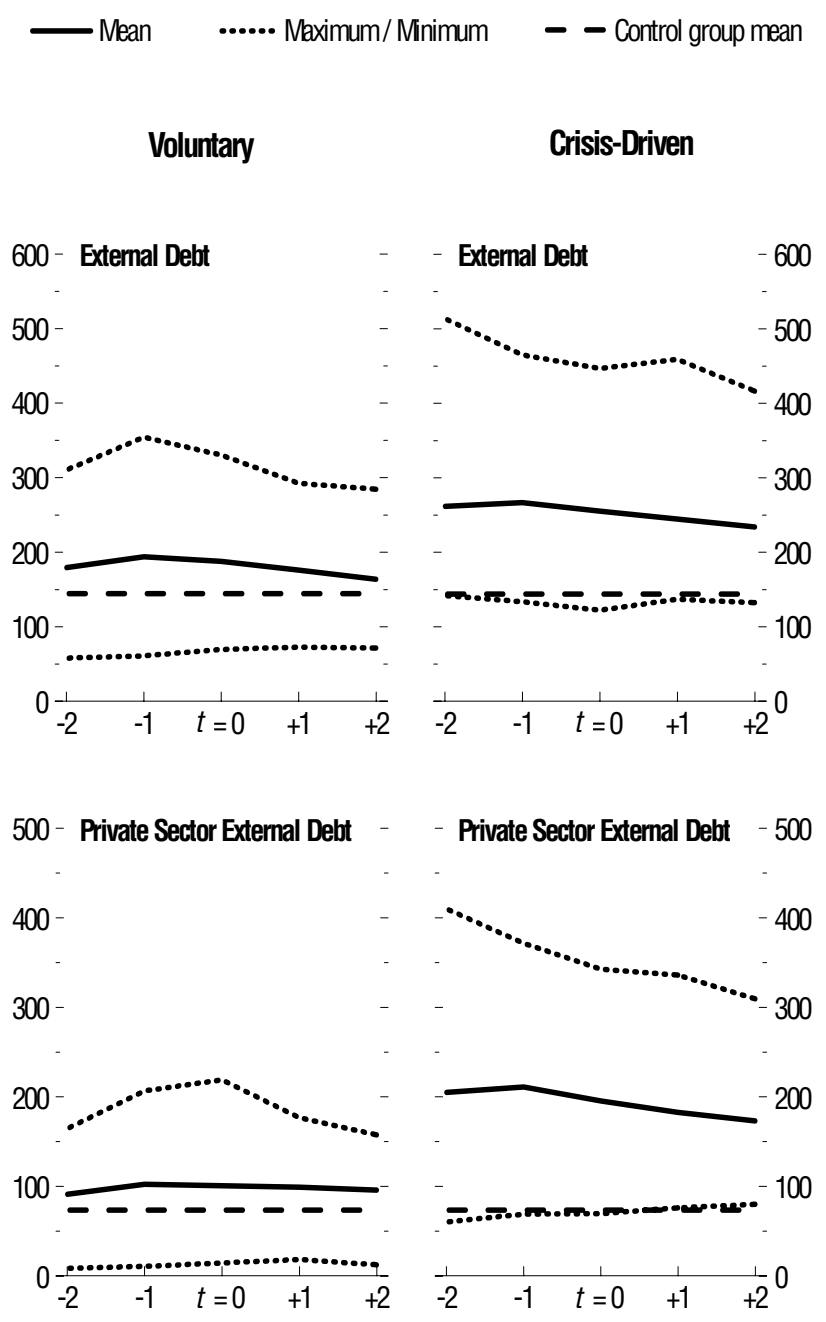

${ }^{1}$ The control group represents countries whose exchange rate regimes are the same as the starting regimes of transitioning countries in periods that are not within three years of a transition. Only countries with observations for all periods shown around the time of transition are included. 
Figure 6. Indicators of Financial Sector Supervision and Development ${ }^{1}$ ( $t=0$ is year of transition; scale 0 to 3 with 3 representing strongest supervision and development)

\section{Quality of Bank Supervision}
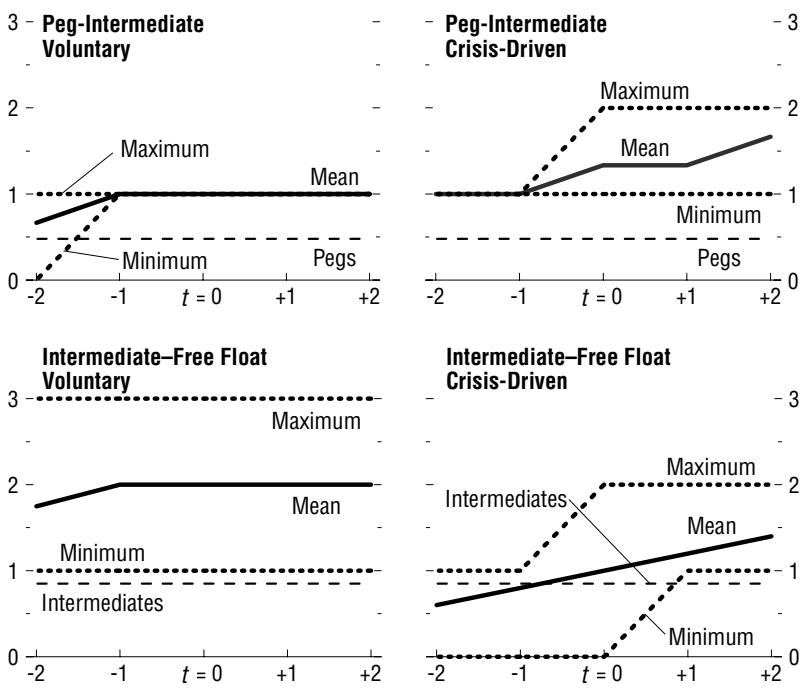

Securities Market Development
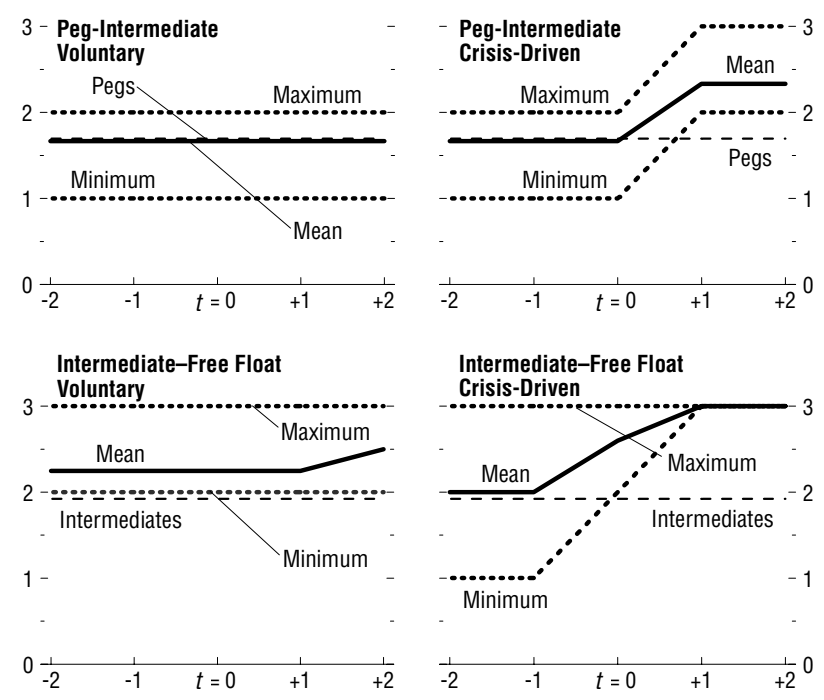

Intermediate-Free Float Crisis-Driven

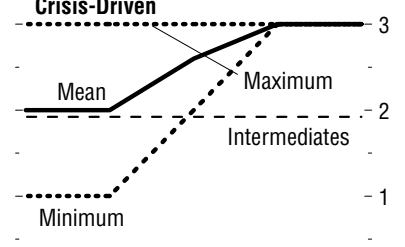

Sources: Abiad and Mody (2003); and author's calculations; see Appendix 1 for variable definitions.

${ }^{1}$ The pegs/intermediates control groups are averages for the countries whose exchange rate regime is the same as the starting regime of transitioning countries in periods that are not within three years of a transition. Only countries with observations for all periods shown around the time of transition are included. 
Figure 7. Indicators of Financial Sector Liberalization ${ }^{1}$ ( $\mathrm{t}=0$ is year of transition; scale 0 to 3 with 3 representing most liberalized)

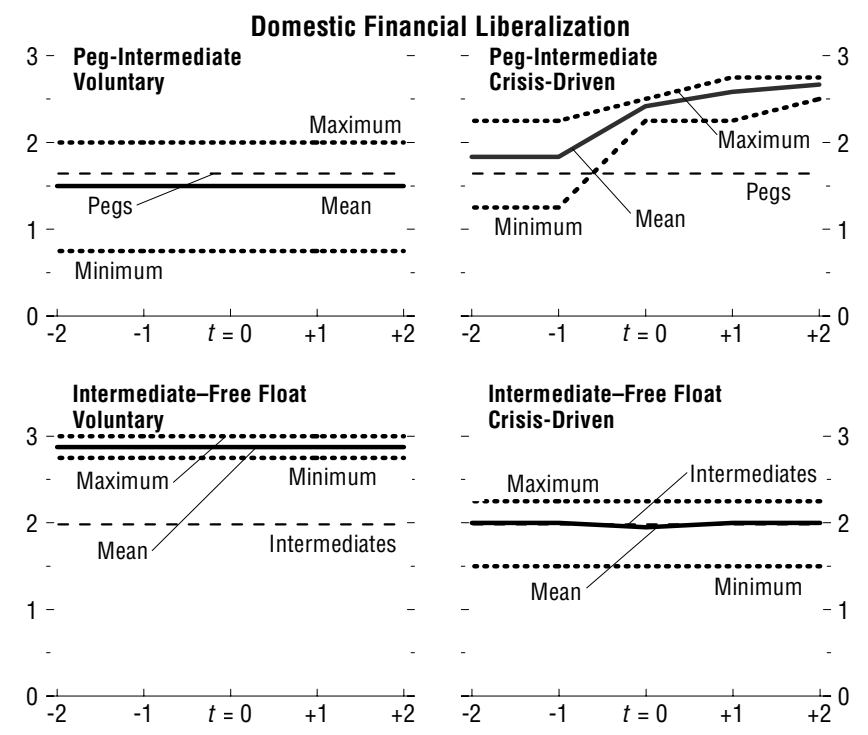

\section{External Financial Liberalization}

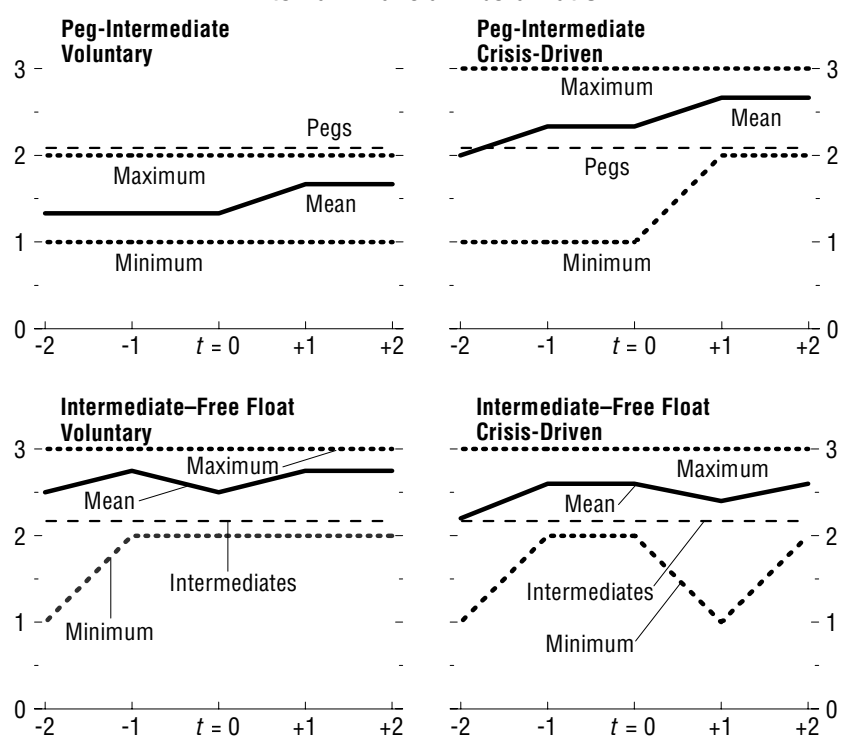

Sources: Abiad and Mody (2003); and author's calculations; see Appendix 1 for variable definitions.

${ }^{1}$ The pegs/intermediates control groups are averages for the countries whose exchange rate regime is the same as the starting regime of transitioning countries in periods that are not within three years of a transition. Only countries with observations for all periods shown around the time of transition are included. 


\section{Methodology And Data}

\section{Classifying Countries' Exchange Rate Regimes}

Until the late 1990s, there was basically one exchange rate classification system in use. This system, which is administered by the IMF, is based on countries' announced (or de jure) exchange rate regimes. However, even though a country may announce a particular exchange rate regime, it may not necessarily implement the policies that are compatible with it. In recognition of this, a number of de facto classification systems have been proposed (IMF (1999), Reinhart and Rogoff (2004), Levy-Yeyati and Sturzenegger (2002 and 2003), and Ghosh et al. (1997)). Although the specific details of the de facto classification systems vary, they all rely to some extent on an assessment of the behavior of actual exchange rates.

The IMF de facto system classifies exchange rate regimes based on the behavior of nominal bilateral exchange rates and reserves in combination with information on countries' exchange rate and monetary policy frameworks and policy intentions obtained during bilateral discussions between IMF staff and country authorities (see Bubula and Ötker-Robe, 2002). By contrast, the Reinhart-Rogoff classification system relies entirely on an examination of the behavior of official or parallel market exchange rates vis-à-vis the currency to which the national currency is permanently or occasionally pegged. There are merits to having a classification system that incorporates a wider set of information, because the behavior of the exchange rate on its own does not always give an accurate picture of exchange rate policy. For example, in a country with a free float, high exchange rate pass-through, and inflation targeting, an exchange rate depreciation (as a leading indicator of inflation) may prompt the monetary authorities to raise interest rates, which in turn will tend to dampen the exchange rate depreciation. ${ }^{34}$ Thus, moving to a float does not necessarily mean that key nominal bilateral exchange rates have to fluctuate very much (see also Genberg and Swoboda, 2004).

The IMF de facto system classifies countries' exchange rate regimes into eight categories which — for the analysis in the paper — are aggregated into four broad categories: pegs, limited flexible, managed floating, and free floating. The "pegs" category includes currency board arrangements and conventional pegs. The "limited flexible" category includes pegs within horizontal bands, crawling pegs, and crawling bands.

34 This argument is particularly important for classifying EM countries' exchange rate regimes because they generally have high exchange rate pass-through compared with industrial countries (Ho and McCauley, 2003) combined with the fact that several of them adopted inflation targeting as they moved to more flexible regimes. Thus, a classification system that relies solely on exchange rate data would be more likely to classify EM countries as having a managed rather than a free float. It also provides an explanation for why the Reinhart-Rogoff classification, for example, does not appear to provide as much support for the "bipolar hypothesis," i.e., that, over time, countries move to the polar extremes of exchange rate flexibility, free floating, or hard pegs. 
The Reinhart-Rogoff classification system can be aggregated into four categories from 15 disaggregated categories that are analogous to the four IMF de facto categories used in the paper (see Rogoff and others, 2003 and 2004). The Reinhart-Rogoff classification also includes a free fall category, which captures periods of macroeconomic instability that are characterized by high inflation and which may therefore be incompatible with any particular exchange rate regime.

\section{Data Definitions and Sources}

Depending on availability of the data, the variables used in the paper cover the period 1991-2003 for the 25 emerging market countries in the Morgan Stanley Capital International index (MSCI), which includes Argentina, Brazil, Chile, China, Colombia, the Czech Republic, Egypt, Hungary, India, Indonesia, Israel, Jordan, Korea, Malaysia, Mexico, Morocco, Pakistan, Peru, the Philippines, Poland, Russia, South Africa, Thailand, Turkey, and Venezuela.

\section{Macroeconomic Indicators}

Real output growth is measured using the annual growth rate of real per capita GDP. The source of the data is the World Economic Outlook (WEO) database.

Inflation is measured using the growth rate of the Consumer Price Index. The source of the data is the IMF's International Financial Statistics (IFS).

Real and nominal effective exchange rates are obtained from the IMF's Information Notice System. An increase in the index denotes an exchange rate appreciation. The data are monthly.

Real exchange rate overvaluation is calculated using the percentage difference between the actual real effective exchange rate (REER, reported in the IMF's Information Notice System) and a Hodrik-Prescott filter of the REER.

The primary fiscal balance as a percent of GDP is obtained from Chapter 3 in the World Economic Outlook (September, 2003).

The current account as a percent of GDP is obtained from the IMF's IFS.

The ratio of external debt to exports of goods and services is calculated as the ratio of total external debt outstanding at year-end divided by exports of goods and nonfactor services plus net total transfers minus net official transfers. The source of the data is the WEO database.

The ratio of private sector external debt to exports of goods and services is constructed as total external debt outstanding at year-end minus the debt outstanding to official debtors divided by exports of goods and nonfactor services plus net total transfers minus net official transfers. The source of the data is the WEO database.

International Reserves in months of imports is obtained from the IMF's IFS. 


\section{Indicators of Monetary Policy Frameworks}

Central bank independence. This measures central bank political and economic independence following the definition by Grilli, Masciandaro, and Tabellini (GMT, 1991). Political independence measures the extent to which the government is involved in the operations of the central bank, where a lower degree of government involvement implies a higher degree of central bank political independence. Economic independence measures the involvement of the central bank in financing the fiscal deficit and in banking supervision. The smaller the involvement the greater the economic independence. The indicator ranges from 0 to 1 , where higher values indicate a higher level of independence. The data, which are available for only ten of the EM countries in the sample for 1989 and 2003, are obtained from Arnone and Laurens (2004).

Dummy for whether a country is inflation targeting or not. The date of adoption of inflation targeting is obtained from Stone and Roger (2004).

\section{Indicators of Financial Sector Supervision and Development}

Quality of banking supervision. This is an aggregate index of the quality of banking supervision which includes (1) banks' adoption of a capital adequacy regulation in line with standards developed by the Bank for International Settlements; (2) the independence of the supervisory agency from the executive's influence and whether it has sufficient legal power and (material) supervisory power; (3) the effectiveness of the supervision; and (4) the extent to which supervision covers all financial institutions.

The securities market development index captures whether a country has taken measures to develop a security or bond market and the openness of its equity market to foreign investors. The measures to develop a securities market include the introduction of auctions for government paper and the establishment of a securities commission, the establishment of equity and bond markets, the opening of these markets to foreign participants, and liberalization of portfolio investments for pension funds and other institutional investors.

The data are obtained from Abiad and Mody (2003). The indicators take values from 0 to 3 , with increasing values indicating stronger bank supervision and greater securities market development. Data are missing for some of the EM countries in the sample.

\section{Indicators of Financial Sector Liberalization}

The index for domestic financial liberalization is constructed as the average of four indicators which measure the extent to which (1) direct credit controls and reserve requirements have been abolished; (2) interest rate controls have been removed; (3) entry barriers against foreign banks have been eliminated; and (4) the banking system has been privatized.

External financial liberalization is an aggregate index which captures whether there are restrictions on capital inflows and outflows, and whether the exchange rate system is unified. 
The data are obtained from Abiad and Mody (2003). The indicators take values from 0 to 3 , with increasing values indicating greater liberalization. Data are missing for some of the EM countries in the sample. 


\section{References}

Abiad, Abdul, and Ashoka Mody, 2003, "Financial Reform: What Shakes It? What Shapes It?" IMF Working Paper 03/70 (Washington: International Monetary Fund). Forthcoming in the American Economic Review.

Arnone, Marco, and Bernard Laurens, 2004, "Measures of Central Bank Autonomy: Empirical Evidence for OECD and Developing Countries, and Emerging Market Economies" (unpublished; Washington: International Monetary Fund).

Bubula, Andrea, and Inci Ötker-Robe, 2002, "The Evolution of Exchange Rate Regimes Since 1990: Evidence from De Facto Policies," IMF Working Paper 02/155 (Washington: International Monetary Fund).

Calvo, Guillermo, and Carmen Reinhart, 2002, "Fear of Floating," Quarterly Journal of Economics, Vol. 117 (May), pp. 379-408. , 2001, "Fixing for Your Life," in Brookings Trade Forum 2000, ed. by Susan Collins and Dani Rodrik, pp. 1-39 (Washington, DC: Brookings Institution).

Calvo, Guillermo, and Frederic Mishkin, 2003, "The Mirage of Exchange Rate Regimes for Emerging Market Countries,” NBER Working Paper No. 9808 (Cambridge, Massachusetts: National Bureau of Economic Research).

Campa, Jose, and Linda Goldberg, 2001, "Exchange Rate Pass-Through into Import Prices: A Macro or Micro Phenomenon?” Staff Report No. 149 (New York: Federal Reserve Bank).

Carare, Alina, Andrea Schaechter, Mark Stone, and Mark Zelmer, 2002, "Establishing Initial Conditions in Support of Inflation Targeting," IMF Working Paper 02/102 (Washington: International Monetary Fund).

Choudhri, Ehsan, and Dalia Hakura, 2001, "Exchange Rate Pass-Through to Domestic Prices: Does the Inflationary Environment Matter?” IMF Working Paper 01/194 (Washington: International Monetary Fund). Forthcoming in the Journal of International Money and Finance.

Detragiache, Enrica, Ashoka Mody, and Eisuke Okada, 2005, "Exits from Heavily Managed Exchange Rate Regimes," IMF Working Paper 05/39 (Washington: International Monetary Fund).

Edison, Hali, and Francis Warnock, 2002, “A Simple Measure of the Intensity of Capital Control," International Finance Discussion Paper No. 7048 (Washington: Board of Governors of the Federal Reserve System). Forthcoming in the Journal of Empirical Finance. 
Eichengreen, Barry, and others, 1998, Exit Strategies: Policy Options for Countries Seeking Greater Exchange Rate Flexibility, IMF Occasional Paper No. 168 (Washington: International Monetary Fund).

Eichengreen, Barry, Paul Masson, Miguel Savastano, and Sunil Sharma, 1999, "Transition Strategies and Nominal Anchors on the Road to Greater Exchange-Rate Flexibility," Essays in International Finance No. 213 (Princeton, New Jersey: Princeton University).

Frankel, Jeffrey A., and Andrew K. Rose, 1996, "Currency Crashes in Emerging Markets: An Empirical Treatment," Journal of International Economics 41 (November), pp. 351-66.

Frankel, Jeffrey, Sergio Schmukler, and Luis Servén, 2002, “Global Transmission of Interest Rates: Monetary Independence and Currency Regime,” NBER Working Paper No. 8828 (Cambridge, Massachusetts: National Bureau of Economic Research).

Gagnon, Joseph, and Jane Ihrig, 2001, "Monetary Policy and Exchange Rate Pass-Through," International Finance Discussion Paper No. 704 (Washington: Board of Governors of the Federal Reserve System).

Genberg, Hans, and Alexander K. Swoboda, 2004, “Exchange Rate Regimes: Does What Countries Say Matter?” (unpublished; Geneva: Graduate Institute of International Studies).

Ghosh, Atish, Anne-Marie Gulde, Jonathan Ostry, and Holger Wolf, 1997, "Does the Nominal Exchange Rate Regime Matter?” NBER Working Paper No. 5874 (Cambridge, Massachusetts: National Bureau of Economic Research).

Goldstein, Morris, and Philip Turner, 2004, Controlling Currency Mismatches in Emerging Markets (Washington: Institute for International Economics).

Grilli, Vittorio, Donato Masciandaro, and Guido Tabellini, 1991, "Political and Monetary Institutions and Public Financial Policies in the Industrial Countries," Economic Policy: A European Forum, Vol. 6 (October), pp. 342-91.

Hausmann, Ricardo, Ugo Panizza and Ernesto Stein, 2001, "Why do Countries Float the Way they Float?” Journal of Development Economics, Vol. 66, pp. 387-414.

Ho, Corrinne, and Robert McCauley, 2003, "Living with Flexible Exchange Rates: Issues and Recent Experience in Inflation Targeting Emerging Market Economies," Bank for International Settlements Working Paper 130, Basel.

Husain, Aasim, Ashoka Mody, and Kenneth Rogoff, 2005, "Exchange Rate Regime Durability and Performance in Developing Versus Advanced Economies" Journal of Monetary Economics, Vol. 52, pp. 35-64. 
IMF, 1999, "Exchange Rate Arrangements and Currency Convertibility: Developments and Issues," World Economic and Financial Surveys (Washington: International Monetary Fund).

IMF, 2001, "International Financial Integration And Developing Countries," Chapter IV, World Economic Outlook, October 2001 (Washington: International Monetary Fund).

Levy-Yeyati, Eduardo, and Federico Sturzenegger, 2002, "Classifying Exchange Rate Regimes: Deeds Versus Words" (Buenos Aires: Universidad Torcuato Di Tella). Available via the Internet: http://www.utdt.edu/ fsturzen.

— 2003, "To Float or to Fix: Evidence on the Impact of Exchange Rate Regimes on Growth," American Economic Review, Vol. 93 (September), pp. 1173-93.

Milesi-Ferretti, Gian Maria, and Assaf Razin, 2000, "Current Account Reversals and Currency Crises: Empirical Regularities," in Currency Crises, ed. by Paul Krugman (Chicago: University of Chicago Press).

Mishkin, Frederic, 1996, "Understanding Financial Crises: A Developing Country Perspective," NBER Working Paper No. 5600 (Cambridge, Massachusetts: National Bureau of Economic Research).

Obstfeld, Maurice, Jay C. Shambaugh, and Alan M. Taylor, 2004, “The Trilemma in History: Tradeoffs Among Exchange Rates, Monetary Policies, and Capital Mobility," NBER Working Paper No. 10396 (Cambridge, Massachusetts: National Bureau of Economic Research).

Reinhart, Carmen, and Kenneth Rogoff, 2004, "The Modern History of Exchange Rate Arrangements: A Reinterpretation," Quarterly Journal of Economics, Vol. 119 (February), pp. 1-48.

Rogoff, Kenneth, Aasim Husain, Ashoka Mody, Robin Brooks, and Nienke Oomes, 2003, "Evolution and Performance of Exchange Rate Regimes," IMF Working Paper 03/243 (Washington: International Monetary Fund). ,2004, Evolution and Performance of Exchange Rate Regimes, IMF Occasional Paper No. 229 (Washington: International Monetary Fund).

Shambaugh, Jay, 2004, "The Effect of Fixed Exchange Rates on Monetary Policy," Quarterly Journal of Economics, Vol. 119 (February), pp. 301-52.

Stone, Mark, and Scott Roger, 2004, "Home on the Range: Country Experiences with Inflation Targeting" (unpublished; Washington: International Monetary Fund). 